\title{
Induced and Spontaneous Neuritogenesis Are Associated with Enhanced Expression of Ganglioside GM1 in the Nuclear Membrane
}

\author{
Gusheng Wu, Zi-Hua Lu, and Robert W. Ledeen \\ New Jersey Medical School, UMDNJ, Department of Neurosciences MSB-H506, Newark, New Jersey 07103
}

\begin{abstract}
Neuro-2a neuroblastoma cells can be stimulated to extend neurites with a number of agents, one of which, neuraminidase, induces terminal differentiation by a mechanism involving enhanced $\mathrm{Ca}^{2+}$ influx. Permeabilization of such differentiated cells with saponin and treatment with cholera toxin B subunit linked to horseradish peroxidase revealed intense staining of the nuclear membrane, indicating the presence of GM1 ganglioside. Unstimulated cells had barely detectable levels of nuclear GM1. Nuclei isolated by sucrose density gradient centrifugation similarly showed intense staining with fluorescently labeled cholera toxin B subunit, in contrast to nuclei from undifferentiated controls. Treatment with chloroform-methanol removed most of the fluorogenic material. Chemical analysis of such nuclei from neuraminidase-treated cells confirmed significant elevation of GM1 above control levels, along with virtual absence of markers for plasma membrane and Golgi apparatus. Cerebellar granule cells from neonatal rats revealed a similar phenomenon following spontaneous neurite outgrowth in culture.
\end{abstract}

[Key words: ganglioside GM1, nuclear membrane, neuritogenesis, Neuro-2a cells, cerebellar, granule cells, GM1 in the nucleus]

Neurite outgrowth as a morphological expression of neuronal differentiation is a complex process involving several regulatory steps at the cell surface and various intracellular compartments. The gangliotetraose family of gangliosides, owing to their rapid accretion during that phase of development, has been postulated to have a role in neuritogenesis and possibly other phases of differentiation (Dreyfus et al., 1980; Ando, 1983; Ledeen, 1984; Yates, 1986; Skaper et al., 1989; Schengrund, 1990; Ledeen and $\mathrm{Wu}, 1992)$. Among the members of this sialoglycolipid family special interest has focused on GM1, the "parent" structure. Affinity-purified antibody to GM1 was reported to block, in a dose-dependent manner, NGF-induced sprouting of chick embryonic dorsal root ganglia (Schwartz and Spirman, 1982; Roisen et al., 1986; Spoerri et al., 1988). GM1 antibody also inhibited neurite formation in the regenerating optic system of

\footnotetext{
Received Aug. 1, 1994; revised Dec. 12, 1994; accepted Dec. 19, 1994.

This work was supported by NIH Grant NS04834. We are happy to acknowledge the helpful advice from Drs. Nicholas Gonatas and Richard Pagano concerning cytochemical methodology, and Dr. Louis Freysz concerning nuclei isolation.

Correspondence should be addressed to Dr. Robert Ledeen, New Jersey Medical School, UMDNJ, Department of Neurosciences, MSB-H506, 185 South Urange Avenue, Newark, NJ $0 \% 103$.

Copyright 1995 Society for Neuroscience $\quad 0270-6474 / 95 / 153739-08 \$ 05.00 / 0$
}

goldfish when applied to retinal explants (Spirman et al., 1982) or injected in vivo (Spirman et al., 1984). An endogenous inhibitor of $N$-acetylgalactosaminyl transferase, the penultimate enzyme in GM1 biosynthesis, effectively inhibited neurite outgrowth in cultured neurons from embryonic chicken retina (Quiroga et al., 1990).

Studies with neuroblastoma cells have also contributed to the concept of a role for GM1 in differentiation. Comparison of several cell lines with differing capacities for neuritogenesis revealed correlation of that property with the cellular level of GM1 (Wu et al., 1991). Cholera toxin B subunit (Ctx B) as well as affinity purified anti-GMl antibody inhibited differentiation of Neuro-2a cells induced by a variety of agents, under conditions where antibody to GM2, a ganglioside on the Neuro-2a membrane (Wu et al., 1991), had virtually no effect (Wu et al., 1994a). Treatment of Neuro-2a and two other neuroblastoma lines with neuraminidase (N'ase), an enzyme which increases cell surface GM1 through hydrolysis of oligosialo members of the gangliotetraose family, caused enhanced neurite outgrowth that was blocked by Ctx B (Wu and Ledeen, 1991). Such differentiation was recently shown to be terminal (Wu ct al., 1994b).

Implicit in virtually all such studies has been the assumption that the primary locus of GMI modulatory activity is the plasma membrane, consistent with evidence of enrichment of GM1 (and glycolipids generally) in this membrane (Ledeen, 1978; Sweeley, 1985; Yu and Saito, 1989). There is, however, growing indication of intracellular localization of glycolipids as well, the nature of which varies from cell to cell (Ledeen et al., 1988; Parkinson et al., 1989; van Genderen et al., 1991; Gillard et al., 1993) and within a given cell according to its metabolic status (Morre et al., 1990). The neuronal nucleus has received little attention in that regard, and only a few reports have suggested the presence of gangliosides and/or other glycolipids in nuclei of other cells (Keenan et al., 1972; Critchley et al., 1973; Symington et al., 1987; Matyas and Morré, 1987). In our recent investigation of Neuro-2a cells undergoing N'ase induced differentiation we observed rather pronounced staining of the nuclear membrane with Ctx-B linked to horseradish peroxidase (Ctx B-HRP), suggestive of the presence of GMI (Wu et al., 1994b). The present study confirms that finding with a combination of biochemical and cytochemical methods, and reveals a similar phenomenon in cerebellar granule cells undergoing differentiation in culture.

\section{Materials and Methods}

Materials. The following items were purchased from the sources indicated: minimum Eagle's medium (MEM), Dulbecco's modified Eagle's 
medium (DMEM), heat inactivated fetal bovine serum (FBS), and antibiotics, GIBCO (Grand Island, NY); tissue culture plasticware, Falcon Labware, VWR Scientific (Piscataway, NJ); Ctx B-HRP and Ctx B-FITC, List Biological Labs (Campfell, CA): UDP- ${ }^{-H}$-galactose, Du Pont-New England Nuclear (Boston, MA); ${ }^{3} \mathrm{H}$-adenosine 5'-monophosphate, Amersham (Arlington Heights, IL); Serocluster 96-well E/A microtiter polystyrene plates, Costar (Cambridge, MA); high-performance thin-layer chromatography (HPTLC), silica gel 60 plates, aluminum backed, EM Science (Cherry Hill, NJ); neuraminidase, type $\mathrm{V}$ from Clostridium perfringens ( $\mathrm{N}^{\prime}$ ase) and from Arthrobacter ureafaciens, and other chemicals, Sigma (St. Louis, MO).

Cell culture. Neuro-2a mouse neuroblastoma cells (American Type Culture Collection, CCL131, Rockville, MD) was subcloned in this laboratory. One subclone (W28) which proved more uniformly responsive to N'ase treatment with respect to neurite outgrowth was used throughout the study. Cells were routinely cultured in DMEM supplemented with $10 \%$ FBS, $50 \mathrm{U} / \mathrm{ml}$ penicillin, $50 \mu \mathrm{g} / \mathrm{ml}$ streptomycin, and $50 \mu \mathrm{g} /$ $\mathrm{ml}$ gentamicin in Falcon $25 \mathrm{~cm}^{2}$ flasks in an incubator with $5 \% \mathrm{CO}$. $95 \%$ humidified air at $37^{\circ} \mathrm{C}$. Cells were passaged every $2-3 \mathrm{~d}$. For cytochemical studies, cells were seeded on glass coverslips placed in six-well plates $\left(4 \times 10^{4} \mathrm{cells} / 2 \mathrm{ml} / \mathrm{well}\right)$ and incubated overnight in the above medium. They were treated with $\mathrm{N}$ 'ase $(C$. perfringens or $A$. ureafaciens, $0.2 \mathrm{U} / \mathrm{ml}$ ) for $2-3 \mathrm{~d}$ and fixed with $4 \%$ paraformaldehyde in phosphate-buffered saline (PBS) (pH 7.2) for 15-30 min. The fixed cells were stored at $4^{\circ} \mathrm{C}$ until cytochemical staining was performed.

Cerebellar granule cells were dissociated from brains of 6-7 d old Sprague-Dawley rats as previously described (Balázs et al., 1990). Briefly, following removal of meninges the cerebellum was chopped to 1 $\mathrm{mm}^{3}$ cuhes and digested with $0.025 \%$ trypsin in $\mathrm{Ca}^{2+} / \mathrm{Mg}^{2+}$-free PBS $(\mathrm{pH} 7.2)$ at $37^{\circ} \mathrm{C}$ for $30 \mathrm{~min}$. Cells were further dissociated by gentle pipetting and filtered through $80 \mu \mathrm{m}$ Nitex mesh. The cell suspension was underlaid with $4 \% \mathrm{BSA}$ and centrifuged at $800 \times g$ for $5 \mathrm{~min}$. The resulting pellet was suspended with MEM supplemented with $10 \%$ FBS and $25 \mathrm{~mm} \mathrm{KCl}, 50 \mathrm{U} / \mathrm{ml}$ penicillin, $50 \mu \mathrm{g} / \mathrm{ml}$ streptomycin, and 50 $\mu \mathrm{g} / \mathrm{ml}$ gentamicin, then seeded at a density of $2 \times 10^{5} / \mathrm{cm}^{2}$ onto polyL-lysine precoated cover slides placed in Falcon tissue culture multiwell plates. Following incubation overnight at $37^{\circ} \mathrm{C}$ in $5 \% \mathrm{CO}_{2}, 95 \%$ humidified air, the cells were treated with $20 \mu \mathrm{M}$ Ara-C and cultured for $6 \mathrm{~d}$. They were fixed with $4 \%$ paraformaldehyde in PBS for 15 min at room temp and then stored at $4^{\circ} \mathrm{C}$ for subsequent cytochemical staining.

Cytochemistry. All steps were carried out at room temp, the same procedure being applied to Neuro-2a (W28) and cerebellar granule cells. The fixed cells were washed three times ( $5 \mathrm{~min} /$ wash) with $50 \mathrm{~mm}$ ammonium chloride in PBS. After 30 min incubation with $0.25 \% \mathrm{H}_{2} \mathrm{O}_{2}$, the cells were permeabilized with $0.2 \%$ saponin in PBS for $2 \mathrm{hr}$. They were then overlaid with $\mathrm{Ctx}$ B-HRP (1.5 $\mu \mathrm{g} \mathrm{Ctx} \mathrm{B} \mathrm{equivalent/ml)} \mathrm{in}$ PBS containing $2 \%$ bovine serum albumin (BSA) and $0.2 \%$ saponin and incubated overnight in a moist chamber. The negative control was Ctx B-HRP preabsorbed for $30 \mathrm{~min}$ with GM1 $(200 \mu \mathrm{g} / \mathrm{ml})$. After removal of Ctx B-HRP, the cells were postfixed for 10 min with $4 \%$ paraformaldehyde plus $0.5 \%$ glutaraldehyde in PBS. HRP reaction was carried out 1-2 min with diaminobenzidine (DAB) as substrate $0.03 \%$ in PBS plus $0.12 \% \mathrm{H}_{2} \mathrm{O}_{2}$ ). The cells were washed two or three times with PBS after each step. Finally they were dehydrated in ethanol and xylene, mounted with Fisher Permount, viewed and photographed with a Nikon Diaphot microscope equipped with oil immersion lens: $60 \times$ and $100 \times$ objectives for Neuro-2a and ccrebcllar granulc cells, respectively.

Freshly isolated nuclei (see below) were fixed with cold $4 \%$ paraformaldehyde for $30 \mathrm{~min}$ at $4^{\circ} \mathrm{C}$ and the suspension applied to poly-Llysine precoated glass slides. Following incubation for 30-60 min at room temp for attachment of nuclei, the latter were rinsed with PBS and exposed to Ctx B-FITC $(1.5 \mu \mathrm{g} \mathrm{Ctx} \mathrm{B} \mathrm{equivalent} / \mathrm{ml})$ in $2 \% \mathrm{BSA} /$ PBS at room temp $1 \mathrm{hr}$. The mixture was removed, the nuclei washed with PBS and mounted in glycerol-water $(1: 1, v / v)$. To distinguish between glycolipid versus glycoprotein receptor for $\mathrm{Ctx} \mathrm{B}$, part of the preparation was immersed in chloroform-methanol $(1: 1, \mathrm{v} / \mathrm{v})$ at room temperature for 15 min followed by staining with Ctx B-HRP and microscope examination as above.

Isolation of nuclei. Nuclei from Neuro-2a (W28) cells were isolated as previously described (Block et al., 1992; Koppler el al., 1993). All operations were carried out at $4^{\circ} \mathrm{C}$. After $2-3 \mathrm{~d}$ of N'ase treatment, the cells were rinsed twice with PBS and quickly frozen at $-70^{\circ} \mathrm{C}$ for $2 \mathrm{hr}$. They were thawed on ice, scraped and collected in a minimum amount of TMD buffer consisting of $20 \mathrm{mM}$ Tris- $\mathrm{HCl}(\mathrm{pH} 7.5), 1 \mathrm{~mm} \mathrm{MgCl}$, and $1 \mathrm{~mm}$ dithiothreitol. In a typical preparation, cells from 20 Falcon 15-cm (diam.) dishes were collected in each group (N'ase-treated and untreated). The cell suspension in TMD buffer (approximately $80 \mathrm{ml}$ ) was divided into two or three portions and subject to three up-down strokes in a Dounce homogenizer with tight-fitting pestle. The homogenate was centrifuged at $800 \times g$ for $10 \mathrm{~min}$, and the pellet was homogenized with $12 \mathrm{ml}$ of $1.2 \mathrm{M}$ sucrose in TMD buffer ( 3 strokes), then mixed with $22 \mathrm{ml}$ of $2.4 \mathrm{M}$ sucrose in TMD buffer (final sucrose $=2.0$ M) and homogenized with a loose-fitting pestle ( 3 strokes). The sample was poured into $40 \mathrm{ml}$ Beckman polyallomer centrifuge lubes and centrifuged $20 \mathrm{~min}$ at $100,000 \times g$ in a Beckman SW28 rotor. The resulting "mixed membrane" fraction (Golgi apparatus, ER, plasma membrane, etc.) occurring as a top layer was collected, washed twice with TMD, suspended in the latter and centrifuged at $1000 \times g$ for $10 \mathrm{~min}$; it was briefly stored as a pellet at $-20^{\circ} \mathrm{C}$ prior to marker enzyme assay (see below). The nuclear pellet was homogenized in $18 \mathrm{ml}$ of TMD buffer containing $0.32 \mathrm{M}$ sucrose in a Dounce homogenizer with tight-fitting pestle (four to six strokes). The homogenate was overlaid on $18 \mathrm{ml}$ of $2.2 \mathrm{M}$ sucrose in TMD buffer in $40 \mathrm{ml}$ polyallomer centrifuge tubes, and centrifuged at $100,000 \times g$ for $20 \mathrm{~min}$. Finally, the nuclear pellet was washed twice with PBS, resuspended in 20 volumes of TMD buffer, centrifuged at $1000 \times \mathrm{g}$ for $10 \mathrm{~min}$, and a portion stored at $-20^{\circ} \mathrm{C}$ for enzyme assay. Another portion was used for ganglioside extraction (see below).

Enzyme assays. Analysis of marker enzymes were carried out on the purified nuclei as well as the "mixed membrane" fraction obtained during the course of isolation (see above). The samples were resuspended in TMD buffer containing $0.25 \mathrm{M}$ sucrose and $0.1 \%$ Triton $\mathrm{X}-100$. The Golgi marker, UDP-galactose: $N$-acetylglucosamine galactosyltransferase was analyzed according to Fleischer and Smigel (1978) employing UDP- ${ }^{3} \mathrm{H}$-galactose and $\mathrm{N}$-acetylgalactosamine as substrates; the ${ }^{3} \mathrm{H}-\mathrm{N}$-acetyllactosamine product was separated from the starting material with a Dowex $2 \times 8$ column. The other Golgi marker, $\alpha$-mannosidase II, was assayed according to Storrie and Madden (1990) with 4-methylumbelliferyl- $\alpha$-D-mannopyranoside as substrate; the resulting chromophore was measured spectrofluorometrically at $448 \mathrm{~nm}$ emission, $364 \mathrm{~nm}$ excitation wavelength. The plasma membrane marker, $5^{\prime}$ nucleotidase, was assayed according to Ozols (1990), with ${ }^{2} \mathrm{H}$-adenosine 5 '-monophosphate as substrate; the liberated ${ }^{3} \mathrm{H}$-adenosine was separated from starting material by anion exchange chromatography. The ER marker, NADH-cytochrome c reductase, was measured according to Fleischer (1981) with ferricytochrome $\mathrm{c}$ as substrate; the resulting ferrocytochrome c was measure spectrophotometrically at $550.5 \mathrm{~nm}$. All assays were normalized to protein content, assayed by the method of Lowry et al. (1951).

Ganglioside isolation and assay. Pellets of purified nuclei in glass tubes were treated with 10 volumes $(<3 \mathrm{ml})$ of chloroform-methanol $(1: 1, v / v)$, sonicated and vortexed intermittently over a $2-3 \mathrm{hr}$ period, and centrifuged to remove insoluble material. The supernatant was treated with concentrated $\mathrm{HCl}$ (final concentration $=0.1 \mathrm{~N} \mathrm{HCl}$ ) and a trace of ${ }^{3} \mathrm{H}-\mathrm{GM} 1$ for calculation of recovery. This was applied to a Sephadex LH-20 column and carricd through the isolation procedure previously described (Byrne et al., 1985). GM1 was quantified by Ctx B-HRP spectrophotometric assay employing 96 well polystyrene microtiter plates as described (Wu and Ledeen, 1988), with the modification that assayed gangliosides were dissolved in ethanol/saline $(1: 1, \mathrm{v} / \mathrm{v})$ before applying to the plate (giving increased adsorption). Total gangliotetraose content was quantified by the same procedure with an additional N'ase treatment step. Gangliotetraose ganglioside patterns were revealed by HPTLC overlay on aluminum-backed strips subjected to N'ase treatment and Ctx B-HRP reaction (Wu and Ledeen, 1988).

\section{Results}

A subclone of Neuro-2a cells (W28), prepared in our laboratory, was employed in these studies because of its superior ncuritogenic response to bacterial N'ase (from $C$. perfringens). One group of cells grown in the presence of this enzyme for a period of 2-3 d showed prolific outgrowth of neurites (Fig. 1) concomitant with increase of GMl on the cell surface (Fig. 2). Control cells (untreated with N'ase) show few neurites and only limited reaction with Ctx B-FITC (Wu and Ledeen, 1991). We previously presented evidence that it is GM1 increase on the cell surface which initially drives neuritogenesis in this system, 

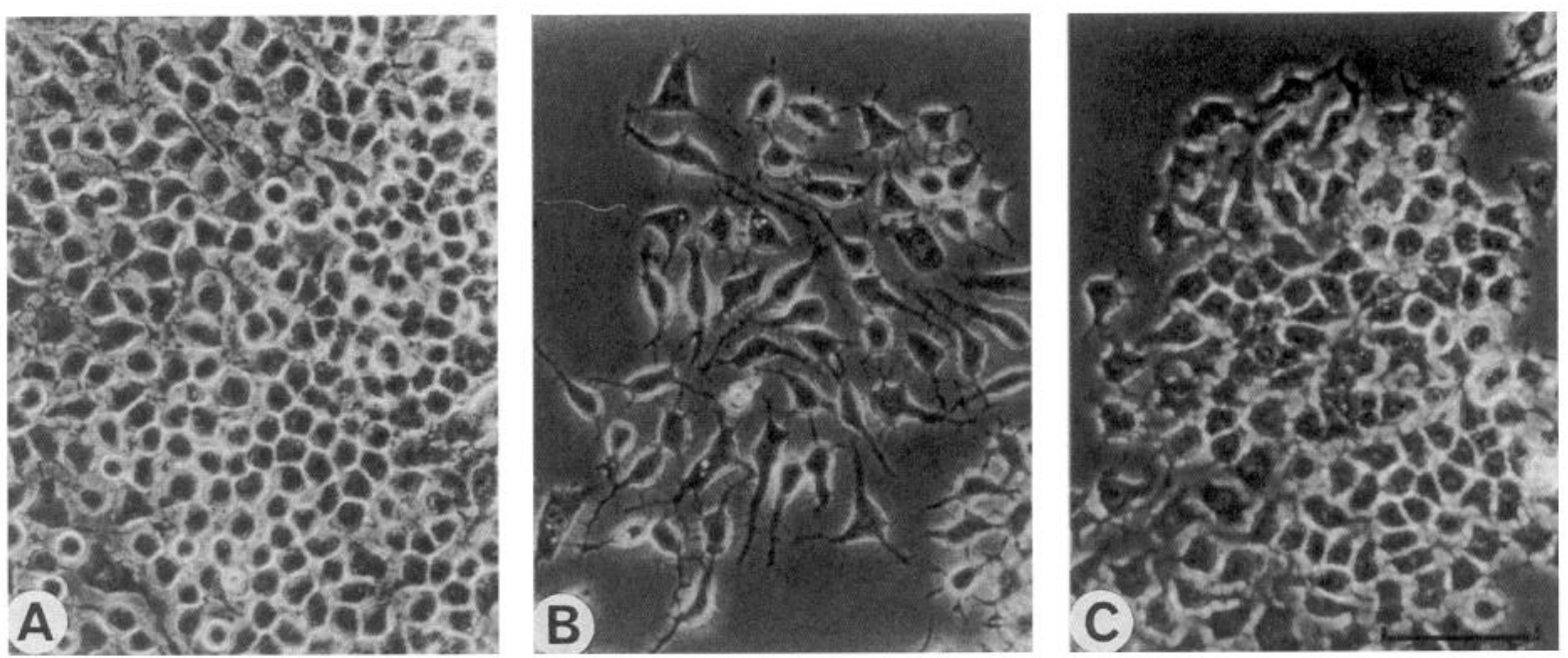

Figure 1. Comparison of neuraminidase effects. Phase contrast micrographs of Neuro-2a (W28) cells treated with neuraminidase from Clostridium perfringens $(B)$ and Arthrobacter ureafaciens $(C)$, each for a period of $3 \mathrm{~d}$ in DMEM with $10 \%$ FBS. $A$ depicts cells grown under the same conditions without enzyme. Scale bar, $100 \mu \mathrm{m}$.

based on blockage of the morphological and $\mathrm{Ca}^{2+}$ changes by Ctx B and anti-GM1 antibody (Wu and Ledeen, 1991). Additional proof was obtained in the present study by treating the cells with Arthrobacter ureafaciens neuraminidase, an enzyme that removes sialic acid from all glycoconjugates-including GM1. Neuro-2a (W28) cells treated in this manner did not accumulate GM1 on the surface (Fig. 2) and failed to extend neurites (Fig. 1), despite the other changes in common with those induced by $C$. perfringens $\mathrm{N}$ 'ase. The latter enzyme did elevate GM1 at the expense of other gangliotetraose gangliosides, as seen in TLC analysis (see below) and cell surface staining with $\mathrm{Ctx} \mathrm{B}$ conjugated to fluorescein isothiocyanate (FITC) (Fig. 2).

To examine intracellular changes, Neuro-2a (W28) cells were grown for $2 \mathrm{~d}$ in the presence of N'ase ( $C$. perfringens), fixed in paraformaldehyde, and treated overnight with saponin plus Ctx B-HRP. After postfixation and brief treatment with diaminobenzidine (DAB) plus $\mathrm{H}_{2} \mathrm{O}_{2}$, light microscopy revealed pronounced staining of the nuclear envelope (Fig. $3 A, B$ ). In contrast, Neuro-2a cells subjected to the same treatment, but without prior exposure to N'ase, showed only faint staining of the nuclear envelope (Fig. $3 C$ ). Staining of the Golgi apparatus and plasma membrane were also evident, these structures being more intensely stained in the differentiated cells. The plasma membrane showed even more intense staining when brought more clearly into focus (not shown). A control experiment, in which N'ase-treated cells were exposed to Ctx B-HRP that was preincubated with an excess of GM1, revealed no staining (Fig. $3 D$ ).

Nuclei isolated from N'ase-treated cells stained positively with Ctx B-FITC (Fig. 4C,D), compared to nuclei from untreated cells which stained very little (Fig. $4 A, B$ ). Treatment of such nuclei with chloroform/methanol removed most of the fluorogenic material (Fig. 4E,F), thus supporting a lipid acceptor for the Ctx B reagent. Thin-layer chromatography (TLC) confirmed the presence of GM1 or a closely related structure (see below).

Biochemical analysis of isolated nuclei from N'ase-treated Neuro-2a (W28) cells, employing microtiter plate picomolar assay with Ctx B-HRP (Wu and Ledeen, 1988), revealed an appreciable level of GM1 that was approximately $5 \times$ higher than control nuclei from untreated cells (Table 1). Gangliotetraose ganglioside content, analyzed by a similar method which in- cluded N'ase conversion of oligosialo structures to GMI, was also elevated but by a smaller percentage. Most of this change in total gangliotetraose level could be accounted for by the elevated GM1, indicating some specificity in the enhanced ganglioside expression. These values are corrected for recovery, based on measurement of remaining ${ }^{3} \mathrm{H}$-GMl following addition of tracer prior to isolation. Purity of the isolated nuclei was assessed by assay of marker enzymes for the two principal repositories of GM1, the Golgi apparatus and plasma membrane (Table 2). Both were essentially negative, in an absolute sense and in comparison with a mixed membrane fraction obtained in the course of nuclei isolation. The marker for endoplasmic reticulum (ER) revealed a low level of activity as expected, considering the continuity between that double membrane structure and the nuclear envelope.

Thin-layer chromatography of gangliosides from the isolated nuclei, employing the Ctx B-HRP overlay method with on-theplate N'ase treatment (Wu and Ledeen, 1988), revealed the presence of the four major gangliotetraose gangliosides in nuclei of both N'ase-treated and untreated cells (Fig. 5). Application of ganglioside quantities representing equivalent nuclear protein from these two samples revealed substantial increase in GM1, consonant with the results of microtiter assay, but relatively little change in the other species. For comparison the TLC patterns of whole cells are also shown, demonstrating conversion of the oligosialo members of the gangliotetraose family to GM1 by N'ase.

Finally, when primary cultures of cerebellar granule cells were subjected to similar treatment with Ctx B-HRP, staining of the nuclear envelope was evident (Fig. $3 E-H$ ). This applied to cells that were cultured for $7 \mathrm{~d}$ and had spontaneously differentiated. Cerebellar granule cells after only $2 \mathrm{~d}$ in vitro showed little if any nuclear staining (not shown).

\section{Discussion}

Transformed cell lines, such as neuroblastoma and pheochromocytoma, have proved highly useful models for the study of neuronal differentiation owing to the diversity of phenotypes available and the possibilities inherent in cell culture manipulation. A further advantage which we have exploited in the pres- 

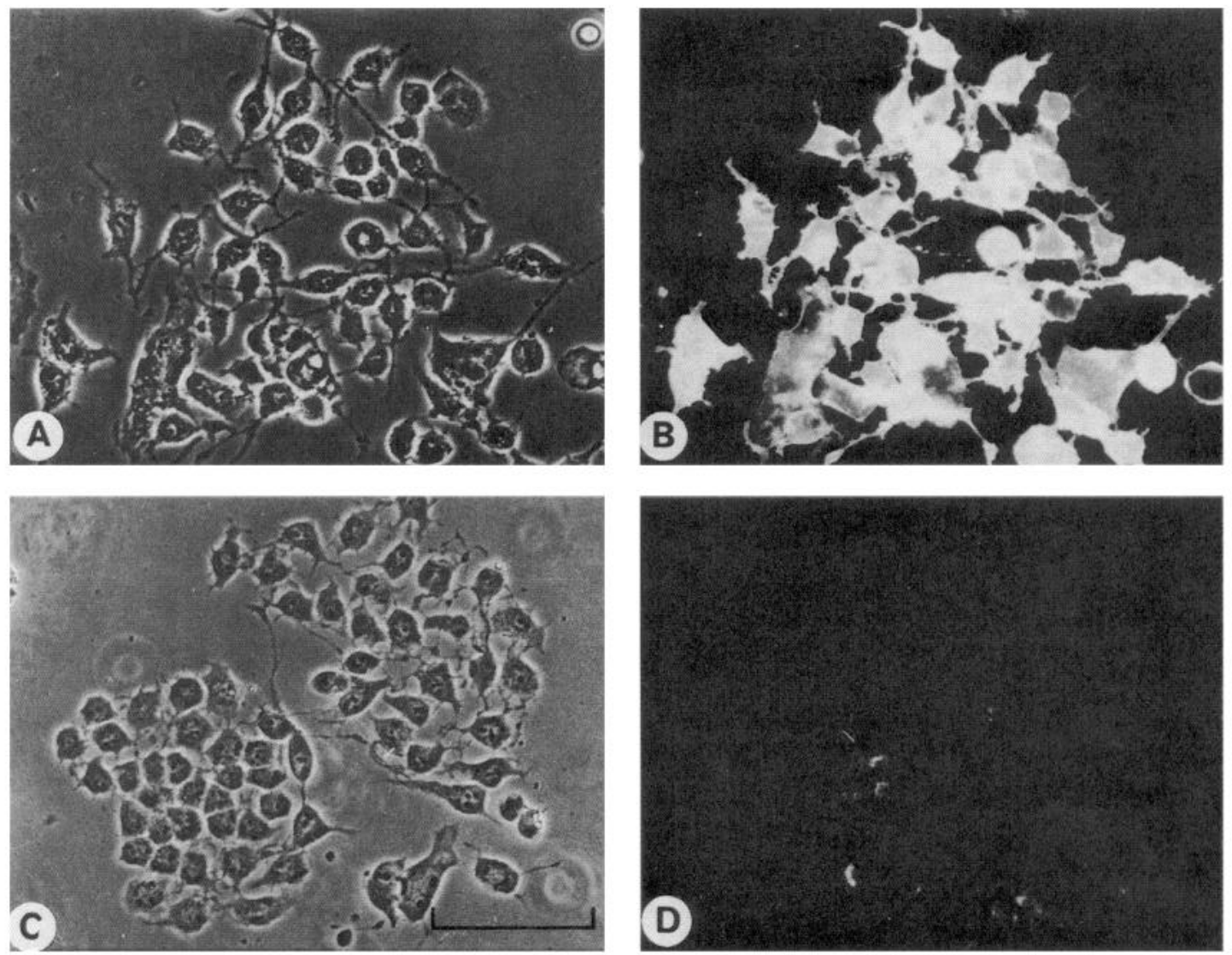

Figure 2. Demonstration of neuraminidase-induced changes in GM1 on cell surface. Cells growing in plastic wells in DMEM with 10\% FBS were treated with neuraminidase from $C$. perfringens $(A, B)$ and $A$. ureafaciens $(C, D)$ for $3 \mathrm{~d}$. After fixing in paraformaldehyde, the cells were stained with Ctx B-FITC $(B, D)$ and photographed with a fluorescent microscope. $A$ and $C$ depict the same cells in phase contrast. Scale bar, 100 $\mu \mathrm{m}$.

ent study is the relatively large quantities of cells that can be harvested for biochemical analyses. This has enabled us to demonstrate the presence of small but measurable amounts of GM1 ganglioside in the nuclei of undifferentiated Neuro-2a cells, and several-fold increase of this ganglioside upon induction of neuritogenesis by $\mathrm{N}$ 'ase (from $C$. perfringens). The prolific neurite outgrowth resulting from this treatment has been attributed to GM1 elevation on the cell surface, as evidenced in blockage of the morphological change as well as the accompanying $\mathrm{Ca}^{2+}$ influx by Ctx B and anti-GMl antibody (Wu and Ledeen, 1991). Support for this interpretation derives from the present finding that Arthrobacter ureafaciens neuraminidase did not induce differentiation in the Neuro-2a system, attributed to the fact that this enzyme removes sialic acid from all glycoconjugates-including GM1. This enzyme thus produces the opposite effect from $C$. perfringens N'ase in relation to surface GM1, but similar changes otherwise. Taken together, these findings strongly suggest that elevation of endogenous GM1 on the plasma membrane is the primary cause of neurite extension in this system, irrespective of other alterations induced by N'ase. This may replicate a key event in normal neuronal differentiation, namely, upregulation of surface GM1, and this in turn is thought to influence neurite extension through $\mathrm{Ca}^{2+}$ modulation (see below).

A crucial point in regard to the biological relevance of this model is that a significant portion of the cells subjected to prolonged N'ase treatment give rise to stable neurites which persist for a period of days following removal of the enzyme (Wu et al., 1994b). This is in contrast to other neuritogenic agents, such as dibutyryl cAMP, which induce neurites that retract following washout; it is perhaps significant that the latter agents do not cause elevation of nuclear GM1 (Wu et al., unpublished observations).

Biochemical data further indicated relative selectivity in ganglioside increase, since the increase in total gangliotetraose gangliosides of the nucleus could be largely, if not wholly, accounted for by GM1. The fact that the oligosialogangliosides (e.g., GDla, GD1b, GT1b) showed relatively little change in the nucleus (Fig. 5) indicates that (1) the applied N'ase did not penetrate into the cell to act directly on the nucleus, and (2) the elevated GM1 detected in the nuclear fraction did not represent plasma membrane contaminants, which would have lost oligosialogangliosides through reaction with N'ase (compare Figs. 2, 5). Rather, it likely arose through upregulation of GM1 synthesis, presumably in the Golgi apparatus, from which it was translocated to the nucleus (see below). However, these and other aspects of mechanism remain to be elucidated. Gangliosides other than the gangliotetraose type (e.g., GM2, GM3) predominate in whole Neuro-2a cells (Wu et al., 1991) and are possibly present in nuclei as well, but have not yet been determined.

Obtaining pure nuclei required careful adherence to the described protocol, including use of a Dounce homogenizer with loose- and tight-fitting pestles at appropriate stages. By this means the ganglioside contents of control and stimulated nuclei shown in Table 1 were reproducibly obtained; we have found that the higher values resulting from less stringent procedures were re- 

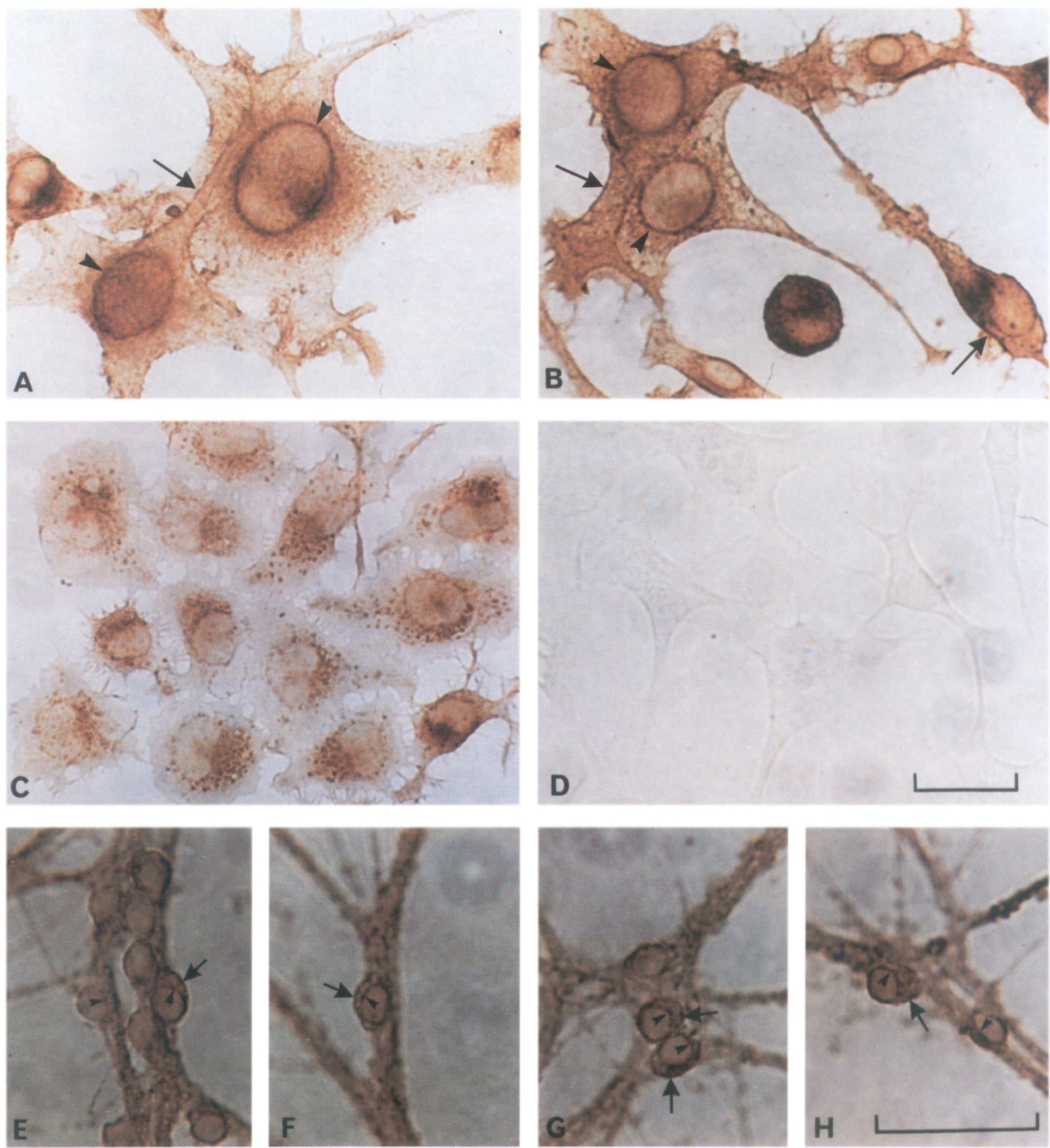

Figure 3. Cytochemical evidence of nuclear GM1. Neuro-2a (W28) cells cultured in DMEM/10\% FBS were treated with N'ase for 2 d (A, B) or maintained as undifferentiated cells without N'ase $(C)$. They were fixed and treated with Ctx B-HRP in PBS containing BSA and saponin. Exposure of N'ase-treated cells to Ctx B-HRP that had been preincubated with excess GM1 revealed no staining $(D)$. Cerebellar granule cells from neonatal rat brain, after culturing $6 \mathrm{~d}$ in MEM/10\% FBS with $25 \mathrm{mM} \mathrm{K}{ }^{+}$, were fixed and stained in the same manner $(E-H)$. Arrowheads indicate stained nuclear membranes; arrows, plasma membranes. Scale bars, $30 \mu \mathrm{m}$.

duced to those in Table 1 by treatment of such isolated nuclei with mild detergent (not shown; cf. Holtzman et al., 1966; Storrie and Madden, 1990). Additional evidence that the double gradient method of isolation employed here yielded nuclei of high purity was provided by the virtual absence of relevant marker enzymes
(Table 2). The presence of low but detectable NADH-cytochrome $\mathrm{c}$ reductase, representing ER, is consistent with the morphological origin of the nuclear envelope (Dingwall and Laskey, 1992). GM1 was shown to be absent from ER in epithelial (Parton, 1994) and liver cells (Matyas and Morré, 1987). 

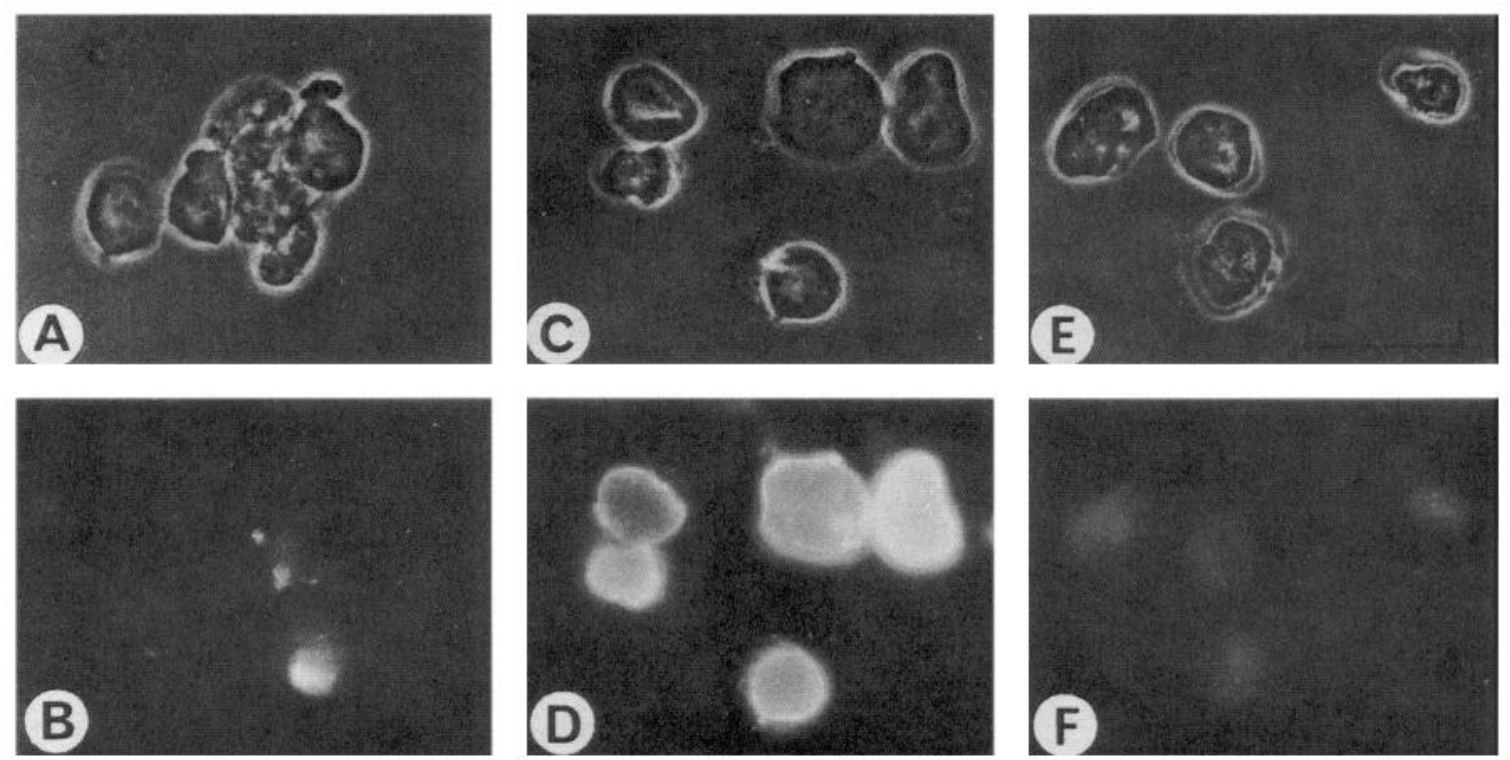

Figure 4. Ctx B-FITC staining of isolated nuclei. Nuclei were isolated from Neuro-2a (W28) cells treated with N'ase for $2 \mathrm{~d}(C-F)$ or medium only $(A, B)$. After fixing and attachment to polylysine-coated glass slides, they were stained with Ctx B-FITC and examined by phase contrast ( $A$, $C, E)$ and fluorescent $(B, D, F)$ microscopy. The nuclei in $E / F$ were extracted with chloroform-methanol prior to staining. Scale bar, $30 \mu \mathrm{m}$.

The cytochemical studies described here (Fig. 3) provide additional evidence for the presence of GM1 in the Neuro-2a nucleus and show it to be localized in the nuclear envelope. They also support in qualitative terms the biochemical finding of substantial differences between nuclei of quiescent and differentiating cells. Nuclei isolated from N'ase-treated cells showed intense fluorescence when treated with Ctx B-FITC (Fig. 4), in contrast to nuclei from unstimulated cells which showed relatively little fluorescence. The possibility that GM1 was acquired adventitiously during nuclei isolation was precluded by the observed nuclear staining of whole cells treated with Ctx B-HRP following permeabilization with saponin. In any population of N'ase-treated cells, those which had differentiated (usually a majority with the W28 clone) showed the intense nuclear staining depicted in Figure 3, whereas those which did not differentiate (generally a minority) showed only the low levels of control cells. This observation, together with the enhanced expression of GM1 on the nuclear membrane of cerebellar granule cells, would preclude the possibility that the elevated GM1 derived from an outside source (e.g., serum) which might have entered the cell during N'ase treatment. Nuclear staining was also seen occasionally in untreated cells, especially those which had differentiated spontaneously (not shown). Uncloned Neuro-2a cells (from the American Type Culture Collection) gave essentially

Table 1. Gangliosides in isolated nuclei of Neuro-2a cells

\begin{tabular}{llll} 
Treatment & $n$ & GM1 & $\begin{array}{l}\text { Ganglio- } \\
\text { tetraose }\end{array}$ \\
\hline Control & 3 & $10.4 \pm 3.4$ & $22.5 \pm 3.7$ \\
N'ase & 3 & $52.5 \pm 6.8$ & $72.6 \pm 10.7$ \\
& & $p<0.001$ & $p<0.01$
\end{tabular}

Gangliosides were extracted from isolated nuclei and purified as described. GMI and total gangliotetraose gangliosides were quantified by the Ctx B-HRP microtiter plate assay ( $\mathrm{Wu}$ and Ledeen, 1988). Values are mean \pm SD pmol/ mg protein. the same results as the W28 clone, except that a lower percentage of cells differentiated under the influence of N'ase.

The high iffinity and specificity with which Ctx B binds to GM1 (Fishman, 1982) makes it an ideal reagent, when suitably conjugated, for cytochemical detection and localization of this (or a closely related) ganglioside. Elimination of most staining of isolated nuclei by extraction with chloroform-methanol (Fig. 4) confirmed that binding of Ctx B was to lipid rather than a membrane protein with similar oligosaccharide chain. Since certain gangliosides with structural similarity to GM1 also serve as receptors for Ctx B (e.g., Masserini et al., 1992), cytochemical evidence alone is not sufficient proof of GM1. The TLC evidence would tend to support GM1 as the receptor molecule in Neuro-2a nuclei, but the diffuseness of the "GM1" band on TLC overlay (Fig. 5) points to the need for rigorous structure determination.

Freeze-substituted postembedding Ctx B-immunogold electron microscopy applied to mouse intestinal epithelial cells revealed significant binding of Ctx B to the plasma membrane and heterochromatin of the nucleus (Parkinson et al., 1989), while recent application of similar methodology to A431 cells showed GM1 to be present in endocytic vesicles, the trans-Golgi network, and the caveolae of the plasma membrane (Parton, 1994). Nuclear staining was not mentioned in the latter study, nor was there evidence of ER staining. Electron microscope autoradiography applied to quiescent Neuro-2a cells revealed GM1 localization in the plasma membrane, lysosomes, and vesicles of the trans-Golgi following endocytosis (Gonatas et al., 1983). The Golgi apparatus was well stained in our Neuro-2a preparations, and showed qualitative evidence of elevated GM1 in the N'asetreated cells (Fig. 3). Considering that the trans-Golgi network is the site of GM1 synthesis (van Echten and Sandhoff, 1993; Rosenwald et al., 1992), upregulation in this organelle would be consistent with the increased demand for GM1 during differentiation, reflected in the elevated levels of the nuclear-as well as plasma membrane (Wu et al., 1994b). 


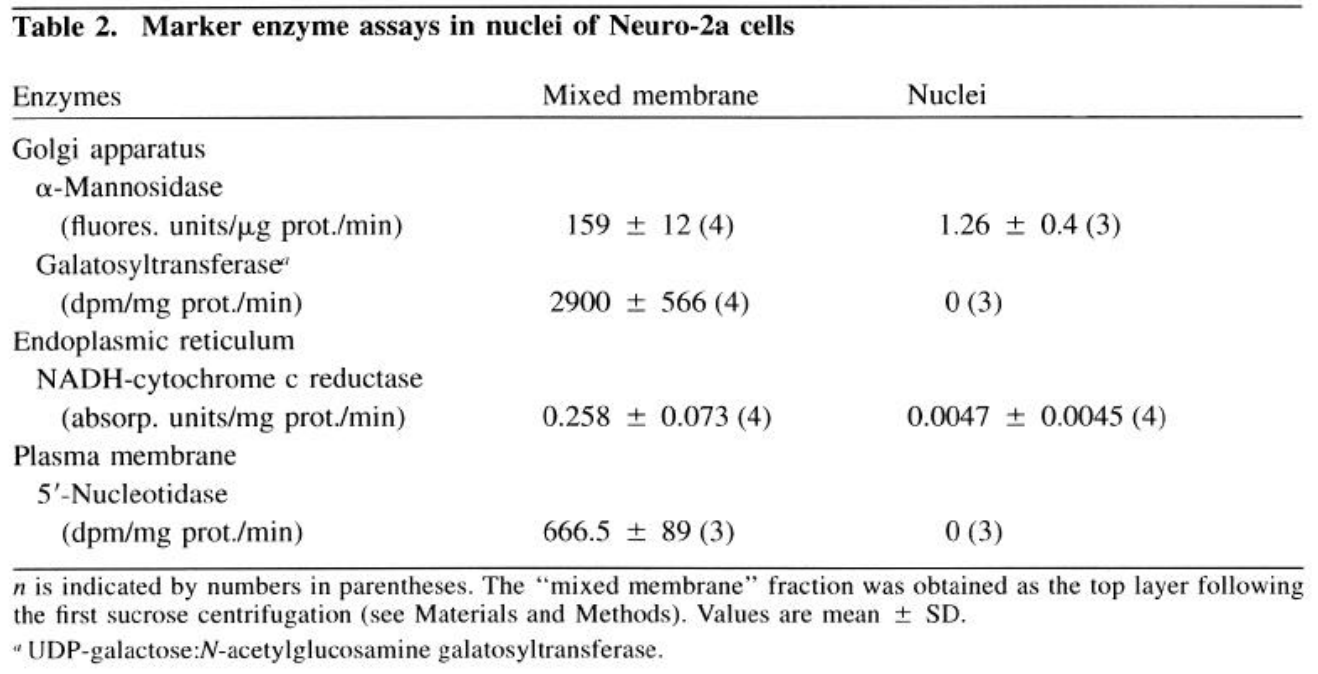

The Ctx B-HRP method applied to cerebellar granule cells in the present study established the presence of GM1 (or closely related molecule) in the nuclear envelope of these cells following $6 \mathrm{~d}$ in culture. It was significant to note that these cells had undergone spontaneous differentiation (without N'ase treat-
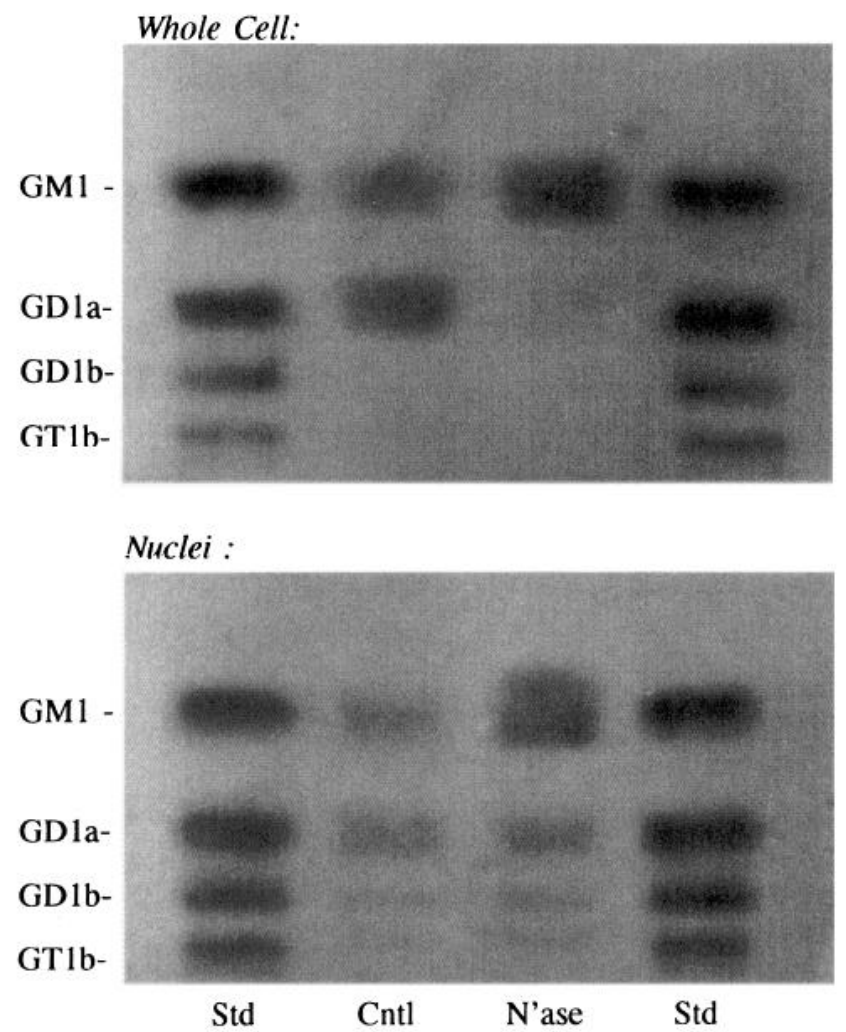

Figure 5. HPTLC of gangliotetraose gangliosides following N'ase treatment. Gangliosides were extracted from purified nuclei isolated from N'ase-treated and control (untreated) Neuro-2a (W28) cells, and subjected to thin layer chromatography. The separated gangliosides were reacted on the plate with N'ase followed by overlay with Ctx B-HRP. Similar treatment was accorded gangliosides from whole cells. N'ase and control samples represent equivalent amounts of protein. Whereas most of the gangliotetraose gangliosides of whole cells were converted by N'ase to GM1, this was not true for nuclei which retained the original pattern of oligosialogangliosides following N'ase treatment and showed significant elevation of GM1. ment), suggesting that upregulation of nuclear GM1 may be a common feature of CNS neurons during neurite extension. Further study is needed to determine the generality of the phenomenon as well as the timing of appearance (and possibly disappearance) of nuclear GM1. Our preliminary observation has indicated little or no nuclear staining of cerebellar granule cells with Ctx B-HRP at an earlier stage of development (e.g., 2-3 d in vitro).

The functional role of GM1 in the nuclear membrane, open to speculation, might be expected to bear some similarity to its role in the plasma membrane, shown to include a multiplicity of functions involving modulation of receptors, enzymes, ion channels, and various other membrane proteins (Skaper et al., 1989; Hakomori, 1990; Ledeen and Wu, 1992). Modulation of $\mathrm{Ca}^{2+}$ flux by endogenous GM1 has received growing attention owing to several recent studies demonstrating diverse manifestations of this behavior in neural and other cells (Spiegel and Fishman, 1987; Wu and Ledeen, 1991; Hillbush and Levine, 1992; Wu and Ledeen, 1994; Carlson et al., 1994). Modulation of T-type $\mathrm{Ca}^{2+}$ channels by GM1 was indicated in Neuro-2a cells (Wu and Ledeen, 1994) while L-type channel modulation was observed in N18 (Carlson et al., 1994), PC12 (Hilbush and Levine, 1992), and cerebellar granule cells (Wu and Ledeen, unpublished observations). Consideration of those findings in relation to the role of intranuclear $\mathrm{Ca}^{2+}$ signaling in neuronal development and regeneration (Holliday et al., 1991; Birch et al., 1992; Utzschneider et al., 1994) suggests that modulation of nuclear $\mathrm{Ca}^{2+}$ during the critical phase of neuritogenesis may be one of the functions of GM1 in the nuclear membrane. It was previously noted that N'ase-induced differentiation, which is $\mathrm{Ca}^{2+}$-dependent and results in $\mathrm{Ca}^{2+}$ influx (Wu and Ledeen, 1991), is fundamentally different from neuritogenesis induced by retinoic acid and dibutyryl cAMP, neither of which depends on extracellular $\mathrm{Ca}^{2+}$ (Wu et al., 1990); this may correlate with the fact that N'ase treatment, unlike the others, leads to enhanced expression of nuclear GM1 along with terminal differentiation. Elucidation of the functional role will be assisted by precise localization of GM1 (or related structure) within the morphologically complex nuclear envelope and may require consideration of other signaling mechanisms as well.

\section{References}

Ando S (1983) Gangliosides in the nervous system. Neurochem Int 5:507-537. 
Balazs R, Hack N, Jorgensen OS (1990) Selective stimulation of excitatory amino acid receptor subtypes and the survival of cerebellar granule cells in culture: effect of kainic acid. Neurosci 37:251-258.

Birch BD, Eng DL, Kocsis JD (1992) Intranuclear $\mathrm{Ca}^{2+}$ transients during neurite regeneration of an adult mammalian neuron. Proc Natl Acad Sci USA 89:7978-7982.

Bluck C, Freyermuth S, Beyersmann D, Malviya AN (1992) Role of cadmium in activating nuclear protein kinase $\mathrm{C}$ and the enzyme binding to nuclear protein. J Biol Chem 267:19824-19828.

Byrne MC, Sbaschnig-Agler M, Aquino DA, Sclafani JK, Ledeen KW (1985) Procedure for isolation of gangliosides in high yield and purity: simultaneous isolation of neutral glycosphingolipids. Anal Biochem 148:163-173.

Carlson RO, Masco D, Brooker G, Spiegel S (1994) Endogenous ganglioside GM1 modulates L-type calcium channel activity in N18 neuroblastoma cells. J Neurosci 14:2272-2281.

Critchley DR, Graham JM, Macpherson I (1973) Subcellular distribution of glycolipids in a hamster cell line. FEBS Lett 32:37-40.

Dingwall C, Laskey R (1992) The nuclear membrane. Science 258: 942-947.

Dreyfus H, Louis JC, Harth S, Mandel P (1980) Gangliosides in cultured neurons. Neuroscience 5:1647-1655.

Fishman PH (1982) Role of membrane gangliosides in the binding and action of bacterial toxins. J Membr Biol 69:85-97.

Fleischer B (1981) The nucleotide content of rat liver Golgi vesicles Arch Biochem Biophys 212:602-610.

Fleischer B, Smigel M (1978) Solubilization and properties of galactosyltransferase and sulfotransferase activities of Golgi membranes in triton X-100. J Biol Chem 253:1632-1638.

Gillard BK, Thurmon LT, Marcus DM (1993) Variable subcellular localization of glycosphingolipids. Glycobiology 3:57-67.

Gonatas NK, Stieber A, Gonatas J, Mommoi T, Fishman PH (1983) Endocytosis of exogenous $\mathrm{GM}_{1}$ ganglioside and cholera toxin by neuroblastoma cells. Mol Cell Biol 3:91-101.

Hakomori S (1990) Bifunctional role of glycosphingolipids. J Biol Chem 265:18713-18716.

Hilbush BS, Levine JM (1992) Modulation of $\mathrm{Ca}^{2+}$ signaling pathway by GM1 ganglioside in PC12 cells. J Biol Chem 267:24789-24795.

Holliday J, Adams RJ, Sejnowski TJ, Spitzer NC (1991) Calciuminduced release of calcium regulates differentiation of cultured spinal neurons. Neuron 7:787-796.

Holtzman E, Smith I, Penman S (1966) Electron microscopic studies of detergent-treated HeLa cell nuclei. J Mol Biol 17:131-135.

Keenan TW, Morré DJ, Huang CM (1972) Distribution of gangliosides among subcellular fractions from rat liver and bovine mammary gland. FEBS Lett 24:204-208.

Koppler P, Matter N, Malviya AN (1993) Evidence for stereospecific inositol $1,3,4,5-\left[{ }^{3} \mathrm{H}\right]$ tetrakisphosphate binding sites on rat liver nuclei. J Biol Chem 268:26248-26252.

Ledeen RW (1978) Ganglioside structures and distribution: are they localized at the nerve ending? J Supramol Struct 8:1-17.

Ledeen RW (1984) Biology of gangliosides: neuritogenic and neuronotrophic properties. J Neurosci Res 12:147-159.

I edeen RW, Wu G (1992) Ganglioside function in the neuron. Trends Glycosci Glycotech 4:174-187.

Ledeen RW, Parsons SM, Diebler MF, Sbaschnig-Agler M, Lazereg S (1988) Ganglioside composition of synaptic vesicles from torpedo electric organ. J Neurochem 51:1465-1469.

Lowry OH, Rosebrough NJ, Farr AL, Randall RJ (1951) Protein measurement with the Folin phenol reagent. J Biol Chem 193:265-275.

Masserini M, Freire E, Palestin P, Calappi E, Tettamanti G (1992) FucGM1 ganglioside mimics the receptor function of GM1 for cholera toxin. Biochemistry $31: 2422-2426$.

Matyas GR, Morre DJ (1987) Subcellular distribution and biosynthesis of rat liver gangliosides. Biochim Biophys Acta 921:599-614.

Morre DJ, Wilkinson FE, Keenan TW (1990) Gangliosides depleted in plasma membrane are directed to internal membranes of rat hepatomas: evidence for a glycolipid sorting defect in hepatocarcinogenesis. Biochem Biophys Res Commun 169:192-197.

Ozols J (1990) Preparation of membrane fractions. Methods Enzymol 182:225-235.

Parkinson ME, Smith CG, Garland PB, van Heyningen S (1989) Identification of cholera toxin-binding sites in the nucleus of intestinal epithelial cells. FEBS Lett 242:309-313
Parton RG (1994) Ultrastructural localization of gangliosides; $\mathrm{GM}_{1}$ is concentrated in caveolae. J Histochem Cytochem 42:155-166.

Quiroga S, Panzetta P, Caputto R (1990) An endogenous inhibitor of $N$-acetylgalactosaminyltransferase inhibits retina neuron differentia tion in culture. Brain Res 508:337-340.

Roisen FJ, Matta SG, Yorke G, Rapport MM (1986) The role of gangliosides in neurotrophic interaction in vitro. In: Gangliosides and neuronal plasticity (Tettamanti G, Ledeen RW, Sandhoff K, Nagai Y, Toffano G, eds), pp 281-293. Padua: Liviana.

Kosenwald AG, Machamer CE, Pagano RE (1992) Effects of a sphingolipid synthesis inhibitor on membrane transport through the secretory pathway. Biochemistry 31:3581-3590.

Schengrund C (1990) The role(s) of gangliosides in neural differentiation and repair: a perspective. Brain Res 24:131-141.

Schwartz M. Spirman N (1982) Sprouting from chicken embryo dorsal root ganglia induced by nerve growth factor is specifically inhibited by affinity purified antiganglioside antibodies. Proc Natl Acad Sci USA 79:6080-6083.

Skaper SD, Leon A, Toffano G (1989) Ganglioside function in the development and repair of the nervous system. Mol Neurobiol 3:173199.

Spiegel S, Fishman PH (1987) Gangliosides as bimodal regulators of cell growth. Proc Natl Acad Sci USA 84:141-145.

Spirman N, Sela BA, Schwartz M (1982) Antiganglioside antibodies inhibit neuritic outgrowth from regenerating goldfish retinal explants. J Neurochem 39:874-877.

Spirman N, Sela BA, Gilter C, Calef E, Schwartz M (1984) Regenerative capacity of the goldfish visual system is affected by antibodies specific to gangliosides injected intraocularly. J Neuroimmunol 6:17 207

Spoerri PE, Rapport MM, Mahadik SP, Roisen FJ (1988) Inhibition of conditioned media-mediated neuritogenesis of sensory ganglia by monoclonal antibodies to GM1 ganglioside. Dev Brain Res 41:7177.

Storrie B, Madden EA (1990) Isolation of subcellular organelles. Methods Enzymol 182:203-225.

Sweeley CC (1985) Sphingolipids. In: Biochemistry of lipids and membranes (Vance DE, Vance JE, eds), pp 361-403. Menlo Park, $\mathrm{CA}$ : Benjamin/Cummings.

Symington FW, Murray WA, Bearman SI, Hakomori SI (1987) Intracellular localization of lactosylceramide, the major human neutrophil glycosphingolipid. J Biol Chem 262:11356-11363

Utzscheinder DA, Rand MN, Waxman SG, Kocsis JD (1994) Nuclear and cytoplasmic $\mathrm{Ca}^{2+}$ signals in developing rat dorsal root ganglion neurons studied in excised tissue. Brain Res 635:231-237.

van Echten G, Sandhoff K (1993) Ganglioside metabolism. J Biol Chem 268:5341-5344.

van Genderen IL, van Meer G, Slot JW, Gueze HJ, Voorhout WF (1991) Subcellular localization of Forssman glycolipid in epithelial MDCK cells by immuno-electron microscopy after freeze-substitution. J Cell Biol 115:1009-1019.

Wu G, Ledeen RW (1988) Quantification of gangliotetraose with cholera toxin. Anal Biochem 173:368-375.

Wu G, Ledeen RW (1991) Stimulation of neurite outgrowth in neuroblastoma cells by neuraminidase: putative role of GMl ganglioside in differentiation. J Neurochem 56:95-104.

Wu G, Ledeen RW (1994) Gangliosides as modulators of neuronal calcium. Prog Brain Res 101:101-112.

Wu G, Vaswani KK, Lu Z, Ledeen RW (1990) Gangliosides stimulate calcium flux in Neuro-2A cells and require exogenous calcium for neuritogenesis. J Neurochem 55:484-491.

Wu G, Lu Z, Ledeen RW (1991) Correlation of gangliotetraose gangliosides with neurite forming potential of neuroblastoma cells. Dev Brain Res 61:217-228.

Wu G, Nakamura K, Ledeen RW (1994a) Inhibition of neurite outgrowth of neuroblastoma Neuro-2A cells by cholera toxin B-subunit and anti-GM1 antibody. Mol Chem Neuropathol 21:259-271.

Wu G, Lu Z, Kozireski D, Ledeen RW (1994b) Irreversible differentiation of N2A cells: GM1 increase in nucleus. Am Soc Neurochem 25:139.

Yates AJ (1986) Gangliosides in the nervous system during development and regeneration. Neurochem Pathol 5:309-329.

Yu RK, Saito M (1989) Structure and localization of gangliosides. In: Neurobiology of glycoconjugates (Margolis U, Margolis R, eds), pp 1-42. New York: Plenum. 